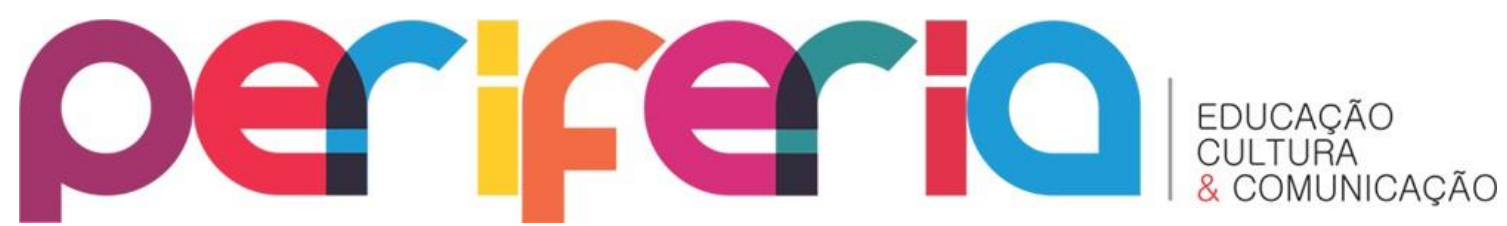

ISSN:1984-9540

DOI: $10.12957 /$ periferia.2019.36362

\title{
UMA ANÁLISE DISCURSIVA DE MEMES DO ENEM 2015
}

\author{
Marcia lone Surdi ${ }^{1}$ \\ UNOCHAPECÓ \\ Andressa Cristina Oliveira da Silva ${ }^{2}$ \\ Universidade Federal da Fronteira Sul
}

\section{Resumo}

A era da internet trouxe à tona uma série de materialidades discursivas diferentes, dentre elas, os memes. Quando algum assunto ou imagem viraliza, as redes sociais tomam para si esse conteúdo e o "reinventam" com o objetivo de manter o humor fresco. Nesse viés, este estudo apresentou como objetivo geral analisar a produção de sentido dos discursos mêmicos que circulam nas redes sociais, e, específicos, analisar a ocorrência da noção de intertexto na materialidade digital meme; compreender as condições de produção dessas discursividades; e analisar a produção de sentido produzida pelos "memes". Para tanto, este estudo foi desenvolvido de acordo com a perspectiva teórico-metodológica da Análise de Discurso, de linha francesa. Para o desenvolvimento de nossa reflexão, constituímos um corpus com memes referentes ao Enem 2015 e desse corpus selecionamos discursividades que foram analisadas pontualmente. Compreendemos que os memes são materialidades digitais, compostos por imagens e textos, tendo relação com algo cotidiano, possuem em seu sentido a intertextualidade de um discurso que já foi proferido em outro momento e que está ligado ao presente, bem como possuem o efeito de ironia como característica marcante.

Palavras-chave: Análise de discurso; discurso; interdiscurso; intertexto.

\footnotetext{
1 Doutora em Letras - Estudos Linguísticos, pela Universidade Federal de Santa Maria. Professora titular da Unochapecó, vinculada à Área de Ciência Humanas e Jurídicas. E-mail: misurdi@unochapeco.edu.br

${ }^{2}$ Graduada em Letras pela Universidade Comunitária da Região de Chapecó - Unochapecó, Chapecó, Santa Catarina, Brasil. Estudante Programa de Pós-Graduação em Estudos Linguísticos (PPGEL), da Universidade Federal da Fronteira Sul (UFFS). E-mail: dressadasilva@unochapeco.edu.br
} 


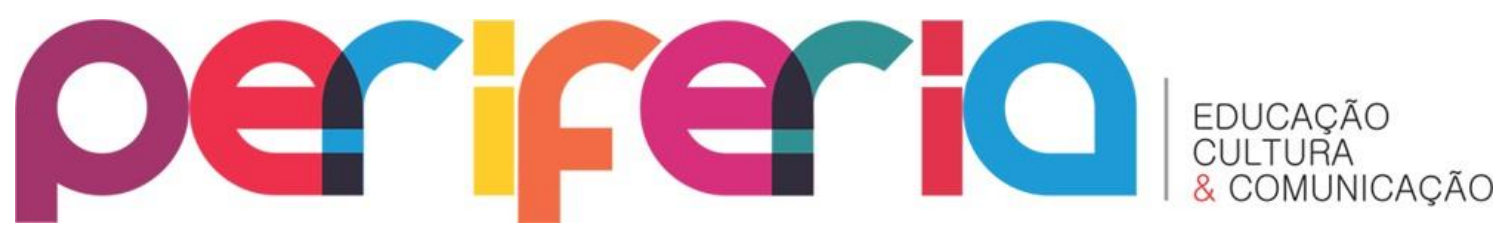

ISSN:1984-9540

DOI: $10.12957 /$ periferia.2019.36362

\title{
A DISCURSIVE ANALYSIS OF MEMES ENEM 2015
}

\begin{abstract}
The era of the internet has brought to light a series of different discursive materialities, among them, memes. When some subject or image becomes virulent, social networks take this content for themselves and "reinvent" it in order to keep their mood fresh. In this bias, this study had as general objective to analyze the meaning production of the social discourses circulating in social networks, and, specifically, to analyze the occurrence of the notion of intertext in the digital materiality meme; understand the conditions of production of these discourses; and analyze the production of sense produced by the memes. Therefore, this study was developed according to the theoretical-methodological perspective of French Discourse Analysis. For the development of our reflection, we constituted a corpus with memes referring to the Enem 2015 and of this corpus we selected discursividades that were analyzed punctually. We understand that memes are digital materialities, composed of pictures and texts, having relation to something everyday, have in their sense the intertextuality of a discourse that has already been uttered at another time and that is connected to the present, as well as have the ironic effect as a striking feature.
\end{abstract}

Keywords: Discourse analysis; discourse; interdiscourse; intertext 


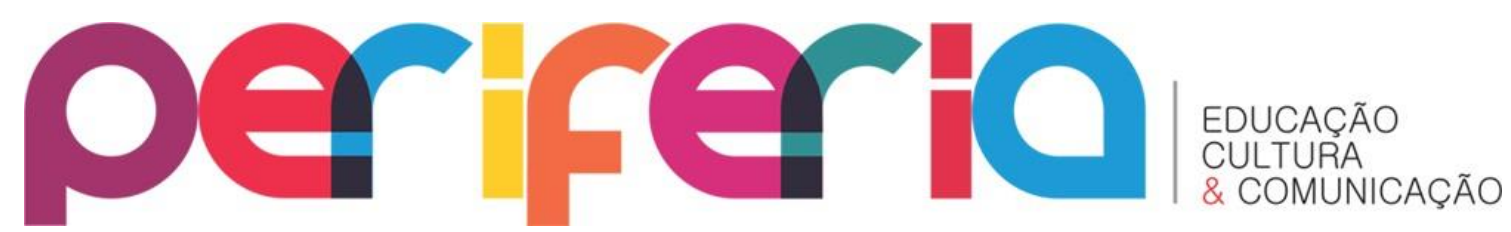

ISSN:1984-9540

DOI: $10.12957 /$ periferia.2019.36362

\section{UNA ANÁLISIS DISCURSIVA DE MEMES DEL ENEM 2015}

\section{Resumen}

La era de internet trajo a la luz una serie de materialidades discursivas diferentes, entre ellas, los memes. Cuando algún sujeto o imagen viraliza, las redes sociales toman para sí ese contenido y lo "reinventan" con el objetivo de mantener el humor fresco. En este sesgo, este estudio presentó como objetivo general analizar la producción de sentido de los discursos mémicos que circulan en las redes sociales, y, específicos, analizar la ocurrencia de la noción de intertexto en la materialidad digital meme; comprender las condiciones de producción de esas discursividades; y analizar la producción de sentido producida por los "memes". Este estudio fue desarrollado de acuerdo con la perspectiva teórico-metodológica del Análisis de Discurso de línea francesa. Para el desarrollo de nuestra reflexión, constituimos un corpus con memes referentes al Enem 2015 y de ese corpus seleccionamos discursividades que fueron analizadas puntualmente. Comprendemos que los memes son materialidades digitales, compuestos por imágenes y textos, teniendo relación con algo cotidiano, poseen en su sentido la intertextualidad de un discurso que ya fue pronunciado en otro momento y que está ligado al presente, así como tienen el efecto de ironía como característica notable.

Palabras clave: Análisis de discurso; discurso; interdiscurso; intertexto. 


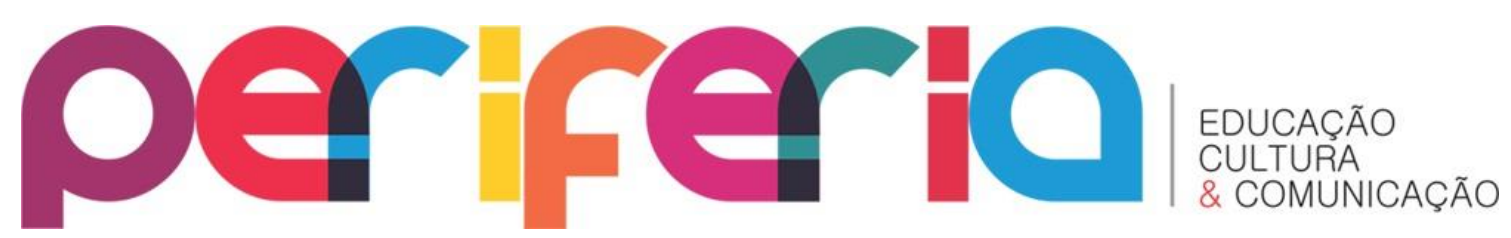

ISSN:1984-9540

DOI: 10.12957/periferia.2019.36362

\section{VAMOS COMEÇAR A ZUEIRA}

A internet trouxe e continua trazendo à tona uma série de materialidades discursivas diferentes, dentre elas, os memes que emergiram nos últimos anos e ficaram famosos. Utilizando imagens e textos produzindo efeitos de sentido de humor, os memes têm uma intensa propagação no meio virtual. Quando algum assunto ou imagem viraliza, as redes sociais tomam para si esse conteúdo e o "reinventam" com o objetivo de produzir um efeito de humor. Praticamente tudo pode dar origem a um meme, seja uma foto, uma notícia ou um vídeo.

De acordo com Zoppi Fontana (2016), meme é um objeto paradoxal por excelência e legitima uma réplica pela repetição. Pelo seu funcionamento, desestabiliza o lugar comum e estabiliza novos sentidos transgressivos, ou melhor, o próprio movimento de transgressão, dado que os sentidos são divergentes e dispersos. A partir desses apontamentos, emerge o problema, seguido das perguntas de estudo: como se dão as construções de sentido dos discursos mêmicos no meio virtual? Quais as condições de produção dessas discursividades? Como os sentidos instaurados pelos memes se sustentam?

Este estudo foi desenvolvido de acordo com a perspectiva teóricometodológica da Análise de Discurso (AD), de linha francesa, assim, mobilizaremos as noções de interdiscurso, intertextualidade, memória metálica, formações imaginárias, discurso lúdico e discurso polêmico.

As redes sociais estão repletas de memes e a dimensão que eles podem tomar é incontrolável. Não há regras para criar, promover ou acabar com eles, pois, a cada novo acontecimento, surge uma nova materialidade digital. É como se eles tivessem vida própria, alimentando-se das curtidas, comentários e, principalmente, dos compartilhamentos.

De acordo com Dias (2007, p. 1)

O discurso sobre a língua nasce, na Internet, sobretudo, como uma reação a um modo de escrita que surge com a expansão da comunicação nas comunidades virtuais e redes sociais, o que, de 


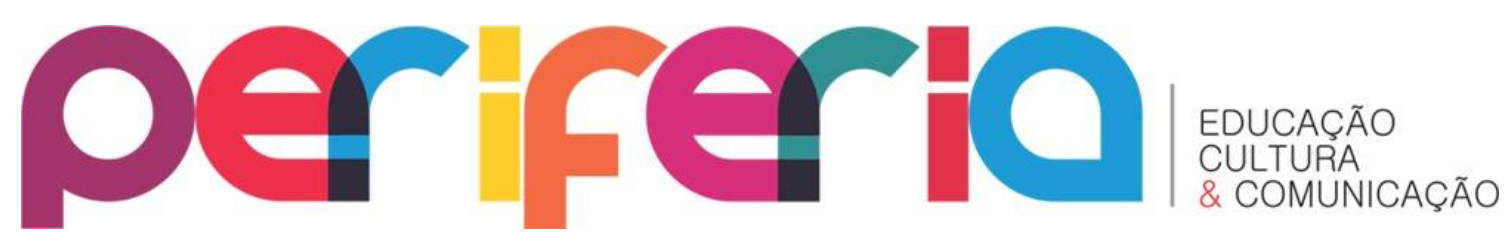

ISSN:1984-9540

DOI: 10.12957/periferia.2019.36362

modo geral, tem se chamado internetês e, de modo específico, encontra subdivisões, dependendo, sobretudo, do fator idade e tribo.

A realização deste trabalho objetivou compreender as construções de sentido do papel desempenhado por componentes mêmicos em espaços virtuais, como forma de representação ideológica e buscou analisar as produções de sentidos que as construções mêmicas proporcionam, partindo de discursos de personagens do mundo real que postam comentários em redes sociais, fomentando, assim, discussões que cooperam para a sobrevivência e propagação dos memes.

A Análise de Discurso objetiva realizar uma reflexão sobre as condições de produção e apreensão do significado de textos produzidos em diferentes campos. Os pressupostos básicos dessa análise podem ser resumidos em dois: (1) o sentido de uma palavra ou de uma expressão não existe em si mesmo; ao contrário, expressa posições ideológicas em jogo no processo sócio-histórico no qual as relações são produzidas; (2) toda formação discursiva dissimula, pela pretensão de transparência e dependência, formações ideológicas (PÊCHEUX, 2009; ORLANDI, 1996).

Para o desenvolvimento de nossa reflexão, constituímos um corpus com memes referentes ao Enem ${ }^{3} 2015$. Desse corpus selecionamos recortes discursivos que nos permitiram analisar a produção de sentido dos discursos mêmicos que circulam nas redes sociais. Nesse percurso, o objetivo da análise, segundo Orlandi (2012a), é a de-superficialização da imagem enquanto texto, buscando, assim, compreender o processo de produção de sentidos nos memes.

Tendo em vista nossa filiação teórica, consideramos como essencial a noção de condições de produção, a fim de compreendermos como cada materialidade se constitui, atentando, em especial, ao modo como a história se inscreve na língua, produzindo determinados efeitos de sentidos (ORLANDI, 2012a).

Consideramos também as formações imaginárias (i) e (ii), as quais funcionam quando compreendemos e analisamos a materialidade digital meme. Sendo

\footnotetext{
${ }^{3}$ O Exame Nacional do Ensino Médio (Enem) avalia conhecimentos obtidos até o término do Ensino Médio. Ele é usado como parte do processo seletivo de mais de mil Instituições de Ensino Superior (IES) públicas e privadas. (GUIA DO ESTUDANTE ABRIL, 2017).
} 


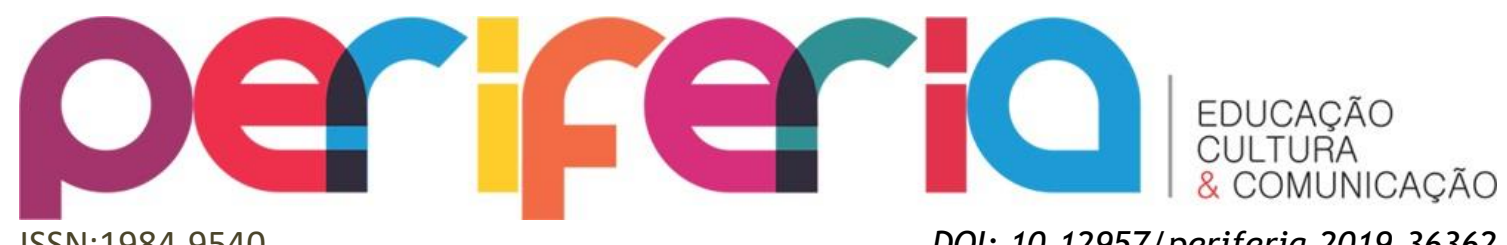

ISSN:1984-9540

DOI: $10.12957 /$ periferia.2019.36362

(i) A formação imaginária que diz respeito a quem são os estudantes que realizam o Enem que funciona no momento da produção do meme.

(ii) A formação imaginária que funciona ao pensar no leitor desse meme, pois se esse leitor não possuir um intertexto para dialogar com o que está sendo dito, a produção de sentido não será materializada da forma esperada.

Ao considerarmos que os memes funcionam pela desestabilização do sentido historicamente constituído, tivemos como objetivo principal, neste estudo, analisar a produção de sentido dos discursos mêmicos que circulam nas redes sociais, assim como compreender as condições de produção dos memes selecionados; e analisar como os sentidos instaurados pelos memes sustentam-se.

\section{SOBRE MEMES? VEJAMOS O QUE TEMOS A DIZER}

\section{0 termo meme}

Não encontramos registros precisos do momento em que o termo meme passou a ser utilizado na Internet. Acredita-se que, aproximadamente por volta dos anos 2000, a palavra ganhou prestígio em um evento que discutia acontecimentos e assuntos virais na web. A partir desse momento, formulou-se uma nova concepção semântica que condiz com o que temos nos dias de hoje, que indica tudo o que se tornou viral na web, ou seja, que se propagou e se destacou rapidamente no espaço cibernético, seja por meio de compartilhamento ou hiperlinks.

Se voltarmos nosso olhar para o campo de estudos da linguagem, de acordo com Souza (2013), o termo meme foi usado pela primeira vez na obra O Gene Egoísta, de Richard Dawkins. Em sua obra, Dawkins (1976) classificou os memes como "replicadores", ou seja, capazes de multiplicar e propagar, gerando assim elementos com as mesmas características, que, por sua vez, repetirão o processo em um ciclo perpétuo. 0 autor postula a ideia de meme - unidade de informação cultural que é replicada de pessoa para pessoa - em analogia ao gene. Dawkins (1976) propôs a 


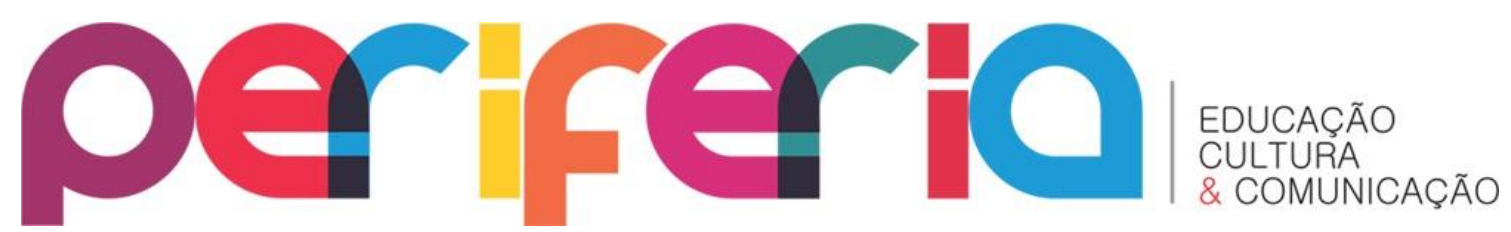

ISSN:1984-9540

DOI: $10.12957 /$ periferia.2019.36362

palavra meme para designar essa nova entidade. 0 termo vem do grego mimeme (imitação), reduzido a duas sílabas para que soasse parecido com "gene".

Conforme Martino (2015, p. 177-178), “imagens, sons, gestos, palavras, melodias, jeitos de se vestir e até mesmo elementos complexos como crenças ou rituais se disseminam pela sociedade na forma de meme". Ele ainda cita Shifman que na sua produção Memes in digital culture, define meme como a facilidade de manipulação e divulgação de materiais na web, transformando-o assim em um fenômeno cultural. Corroborando, Carvalho e Kramer (2013, p. 86) citam que os memes "são modismos usados durante um período de tempo, muito populares nas comunicações por redes”. Candido e Gomes (2015, p. 1298), ao analisá-los, apontam ainda que "retratam geralmente situações do dia a dia de forma cômica e satírica".

Partindo para o viés da AD, compreendemos o meme como uma materialidade digital, nos termos de Dias (2013), materialidade digital é a escrita na Internet tomada na sua relação com o mundo. Essa "forma material" do texto na internet é compreendida a partir de suas condições de produção.

Coelho (2014) desenvolveu uma dissertação intitulada Brace yourselves, memes are coming: formação e divulgação de uma cultura de resistência através de imagens da internet, na qual visou abordar a utilização de imagens da internet, conhecidas como memes, buscando compreender seus efeitos como elemento de divulgação cultural. Conforme o autor,

[...] meme é um gesto de interpretação frente a memória metálica, filiado à memória discursiva da chamada cultura dos memes. Assim dizendo, a utilização de um determinado meme para uma situação específica cria um posicionamento político frente à rede, uma leitura possível de um elemento produzido em série (COELHO, 2014, p. 19)

Como afirma Coelho (2014), os memes apresentam-se como unidades fragmentadas de um fato, ou seja, o sentido do meme não é superficial, não está na imagem e no texto materializado, mas, sim, na contextualização com outros fatos que se replicam por meio de um processo coletivo. 


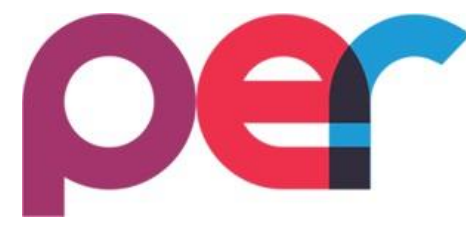

ISSN:1984-9540

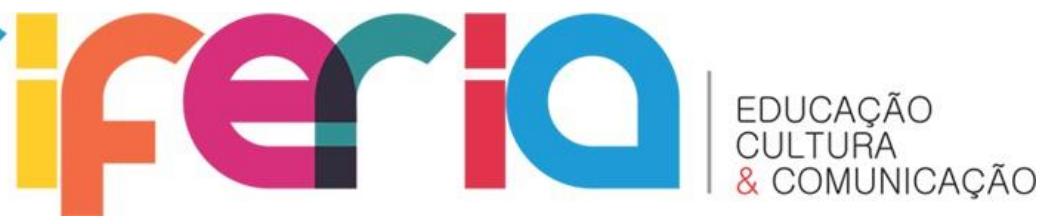

DOI: $10.12957 /$ periferia.2019.36362

Partindo do pressuposto que os discursos circulam em diversos meios e produzem sentido, Coelho (2014) explica que a internet cria grupos próprios formados por sujeitos históricos e ideologicamente constituídos que se agrupam por afinidade e por compartilhar dos mesmos pensamentos. Esses grupos criam linguagens próprias com fortes traços de suas ideologias. Utilizando essa linguagem específica, cria-se uma relação entre sujeito e sentido, pois se o sujeito não fizer parte desse grupo poderá não entender o sentido que o meme produz.

Levando em consideração a longevidade e sucesso dos memes, aponta Coelho (2014) que os memes têm vida curta, nem todos alcançam sucesso, pois estão ligados a fatos e ocorrências cotidianas. Esse tipo de materialidade, por estar associado a fatos novos, possui um tempo de vida, o seu tempo de sobrevivência também está associada ao seu poder de replicação e propagação. Um meme pode ser criado e sua linguagem não ser entendida nas redes pelo leitor, dessa forma, sua longevidade é muito curta e em questão de horas pode sumir.

\section{Meme: linguagem e materialidade digital}

Os discursos produzidos no espaço virtual e materializados em forma de memes, sendo estes compreendidos como recortes discursivos replicados por meio de redes sociais, apresentam concordância e apropriação por parte dos sujeitos das falas de personagens do mundo real. Essa linguagem é utilizada como prática social e ideológica. Compreendemos, neste artigo, como recortes discursivos, a manifestação discursiva dos memes, compreendendo que podem ser formados de linguagem verbal e não verbal. Assim, "o discurso dos memes revela-se como uma linguagem em uso, a prática social que se manifesta sob a forma de imagens e textos que possuem uma vasta intencionalidade discursiva". (COELHO, 2014, p.5).

Como já sinalizamos na introdução deste trabalho, tomamos como fio condutor os pressupostos teórico-analíticos da Análise de Discurso, de viés francês, tal como vem se desenvolvendo no Brasil. A AD propõe que o discurso é efeito de sentido entre locutores - sujeitos sócio-históricos e ideologicamente constituídos. 


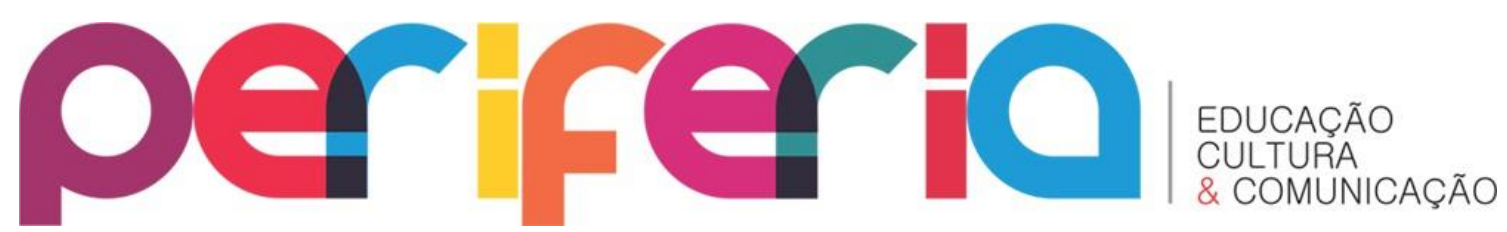

ISSN:1984-9540

DOI: $10.12957 /$ periferia.2019.36362

Assim, o discurso é marcado ideologicamente, submetido à história e acontece em e a partir de condições determinadas. (ORLANDI, 2012a). As principais categorias analíticas mobilizadas neste trabalho foram às noções de intertexto, interdiscurso e condições de produção. No caminho teórico-metodológico empreendido, não há separação entre teoria e análise, já que "[...] o dispositivo teórico-metodológico da análise de discurso se constrói num movimento pendular entre teoria e análise". (PETRI, 2013, p. 45). Desse modo, nosso percurso é marcado por um "vai-e-vem contínuo" entre as análises e a própria explicação de fundamentos teóricos que sustentam o estudo. (CASTELLANOS PFEIFFER, 2000, p. 10).

Os memes do Enem 2015 analisados foram organizados a partir de temporalidades, considerando as discursividades que são criadas e compartilhadas antes, no dia e depois da realização do exame.

Conforme Dias (2015, p. 975), a temporalidade é:

[...] constituída por outros paradigmas que escapam à cronologia. 0 tempo do digital é o do acesso. Um arquivo digital é sempre atual ou, melhor dizendo, passível de atualização pelo acesso. (Ex. ao comentar uma postagem do facebook, independentemente da data em que foi postada, ela se atualiza na linha do tempo).

Essas temporalidades foram construídas a partir das temporalidades que são encontradas no site do Enem, conforme a ilustração 1: Cronograma de aplicação da prova: 


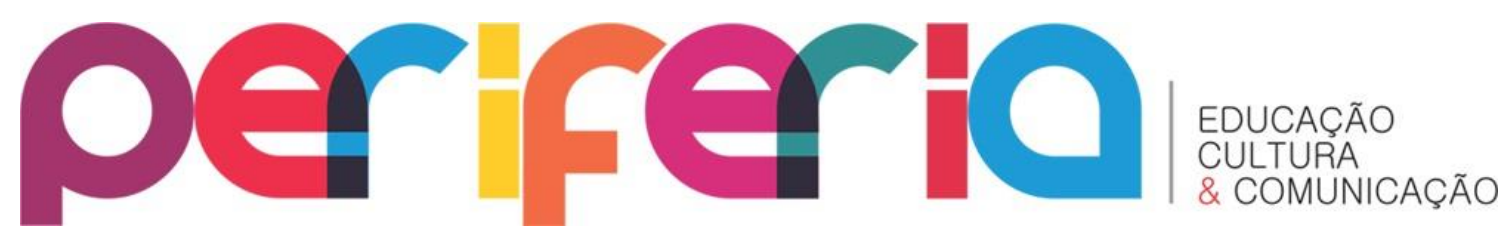

ISSN:1984-9540

DOI: $10.12957 /$ periferia.2019.36362

Imagem 1:

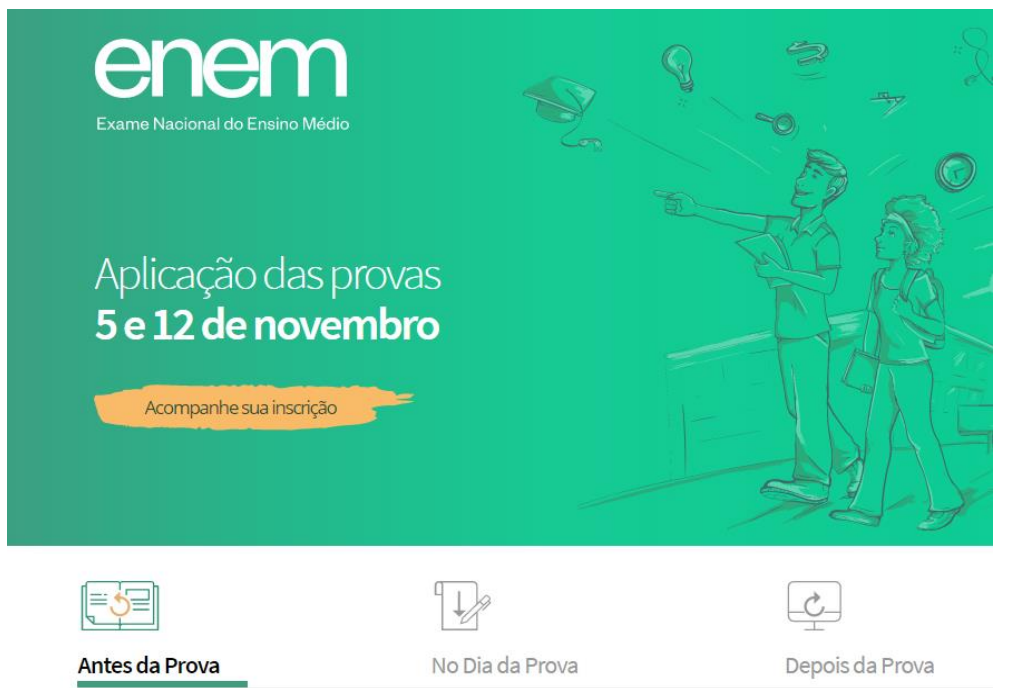

Fonte: http://enem.inep.gov.br/\#/antes?_k=bwa1fn. Acesso em: 27 nov. 2015.

Compreendemos que essas temporalidades têm relação com as condições de produção dos memes.

Segundo Petri (2004, p.157),

[...] quando falamos de condição estamos nos referindo à circunstância, a algo que resulta de determinada "situação", algo que não nos dá liberdade de escolha: a condição que se impõe e se aceita, ela está dada, essa é a sua propriedade essencial. A condição é anterior à produção, ela determina a constituição do produto, pois interfere no processo de produção.

Consideradas em um sentido mais amplo, as condições de produção incluem o contexto sócio-histórico e o aspecto ideológico. É pelo discurso que melhor se compreende a relação entre linguagem/ pensamento/ mundo, porque o discurso é uma das instâncias materiais concretas dessa relação (ORLANDI, 2012c), por meio das condições de produção que se podem compreender, os sujeitos e a situação, relacionados à memória.

Segundo Orlandi (2012c), podemos considerar as condições de produção tanto em sentido estrito, quando nos referimos ao contexto imediato, isto é, o agora, a 


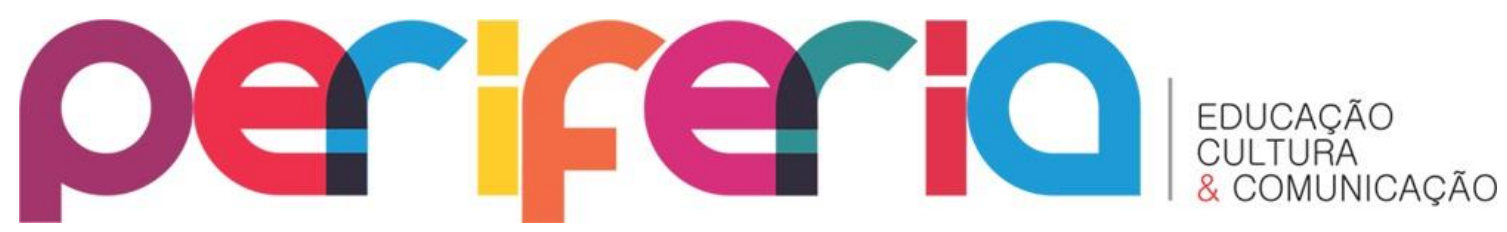

ISSN:1984-9540

DOI: $10.12957 /$ periferia.2019.36362

enunciação, quanto em sentido amplo, quando nos referimos ao contexto sóciohistórico e ideológico. As condições de produção em contexto amplo remetem a um conjunto de formulações já feitas e esquecidas, que trabalharão de modo a determinar o que dizemos. Para a Análise de Discurso, as condições de produção e a memória discursiva trabalharão de forma conjunta, pois a memória é o saber discursivo que torna possível todo dizer.

O funcionamento concomitante das temporalidades antes, durante e depois pode ser visualizado no Meme 1:

Imagem 2:

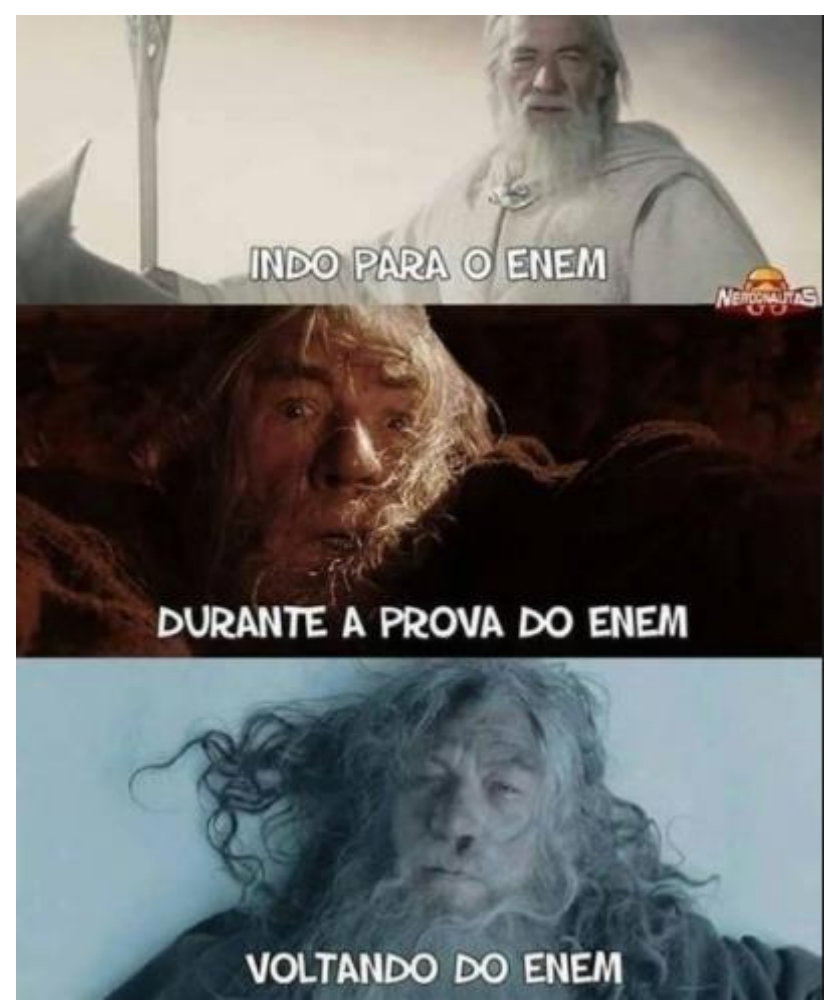

Fonte: http://g1.globo.com/educacao/enem/2015/noticia/2015/10/memesfazem-enem-ter-mais-de-um-milhao-de-mencoes-no-twitter.html. Acesso em: 27 nov. 2015.

A partir da perspectiva teórica da $A D$, compreendemos que os memes não são discursos prontos ou imagens específicas ou mesmo um texto, são um tipo de 


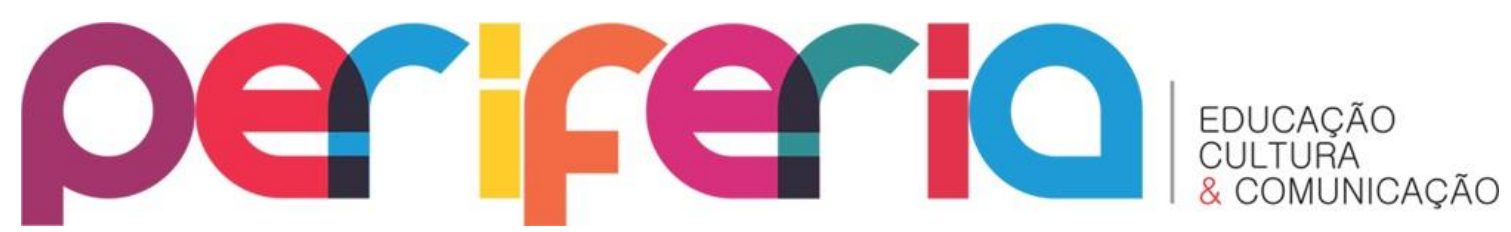

ISSN:1984-9540

DOI: $10.12957 /$ periferia.2019.36362

linguagem que compreende o uso de linguagem verbal e não verbal e, na maioria das vezes, produzem efeitos de sentido irônico que é utilizado para se dizer o que pensa de uma forma humorística, é um recorte que permite a textualização do discurso.

Assim como aponta Coelho (2014, p. 19), estamos compreendendo que

[...] utilização de um determinado meme para uma situação específica cria um posicionamento político frente à rede, uma leitura possível de um elemento produzido em série. Os sentidos, através da replicação, se espalham e transbordam, e é através deste gesto que o meme se altera, e se ressignifica.

A produção de sentidos na leitura do Meme 1 não se restringe somente ao que está exposto na imagem, tem um sentido mais amplo. Para entender esse meme, o sujeito, consequentemente, precisa compreender o sentido instaurado tendo conhecimento do que supostamente inspirou a formulação do mesmo, bem como sua utilização, sobrevivência e então a replicação nas redes sociais. Nesse viés, entram em funcionamento as noções de interdiscurso e intertextualidade.

Nas palavras de (ORLANDI, 2012c) o interdiscurso é o conjunto de dizeres já ditos e esquecidos que determinam o que dizemos, sustentando a possibilidade mesma do dizer. Para que nossas palavras tenham sentido é preciso que já tenham sido ditas. Dessa forma, para instaurar um sentido para o Meme 1, o sujeito que o lê precisa ter o interdiscurso sobre a saga $O$ senhor dos anéis e $O$ Hobbit, do escritor J.R.R.Tolkien, já dito e esquecido em sua memória, o interdiscurso tem íntima ligação com a memória. Para Orlandi (2012b), a memória também faz parte do discurso, logo, a maneira como ela surge induz às condições de produção do discurso, e assim a memória é considerada "interdiscurso".

Afirma Orlandi, em seu livro Discurso e Leitura:

De forma bastante resumida, podemos dizer que há relações de sentidos que se estabelecem entre o que um texto diz e o que ele não diz, mas poderia dizer, e entre o que ele diz e o que outros textos dizem. Essas relações de sentido atestam, pois, a intertextualidade, isto é, a relação de um texto com outros (existentes, possíveis, ou imaginários). Os sentidos que podem ser lidos, então, em um texto não estão necessariamente ali, nele. $O(s)$ sentido(s) de um texto 


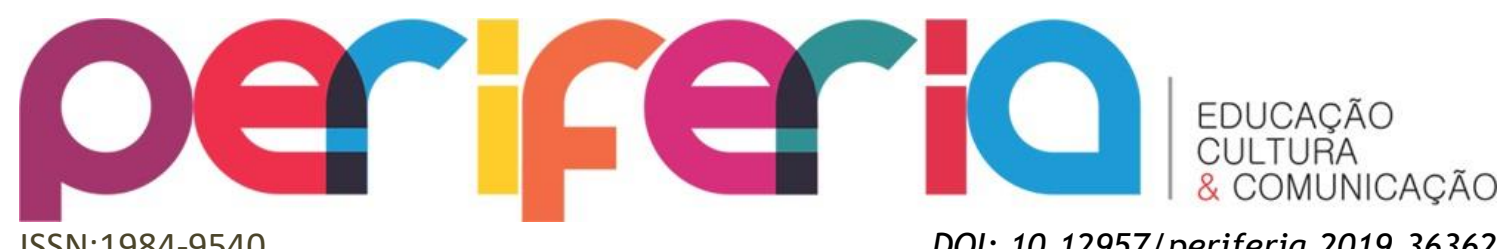

ISSN:1984-9540

DOI: $10.12957 /$ periferia.2019.36362

passa $(m)$ pela relação dele com outros textos. (ORLANDI 2012b, p. 11).

Assim, os memes fazem parte da rede de discursos de internautas e estabelecem uma relação de dependência com o interdiscurso e mesmo pretensamente livre de amarras institucionais, os memes são oriundos e constituintes do interdiscurso (SCHONS; FUKUE, 2012).

Dessa forma, como o texto mêmico dialoga com outros textos já existentes, vamos ao encontro com a intertextualidade da leitura citada por Orlandi.

Há vários elementos que podem determinar a previsibilidade das leituras de um texto. Os sentidos têm sua história, isto é, há sedimentação de sentido, segundo as condições de produção da linguagem. Um texto tem relação com outros textos (a intertextualidade). (ORLANDI, 2012, p.42)

É possível observar no Meme 1 a ocorrência da intertextualidade do discurso. Ela traz como texto não verbal a imagem do personagem dos romances $O$ senhor dos anéis e 0 Hobbit, representando sua decadência com o passar da narrativa, associando ao texto verbal antes, durante e depois do Enem. A ocorrência do meme tem como objetivo representar o processo de realização da prova, caracterizada como cansativa e desgastante, por exigir do aluno mais de cinco horas e meia para a resolução das questões. A questão é bastante priorizada e compartilhada nas redes sociais. Como consequência, inúmeros memes nesse sentido são criados para representar e criticar, humorística e ironicamente, esse episódio.

Levando em consideração que os memes são compostos por recortes de outros textos, dando origem a uma nova formulação, para que a produção de sentido seja concretizada é imprescindível que o sujeito que o lê tenha tido algum contato com esse texto da escritora J.R.R. Tolkien. É interessante notar que os memes, de modo geral, apresentam como característica a ironia, sendo que ela só será entendida e materializada na interação que se estabelece entre os três sujeitos citados por Orlandi (2012). Sobre a ironia, a autora explica que: 


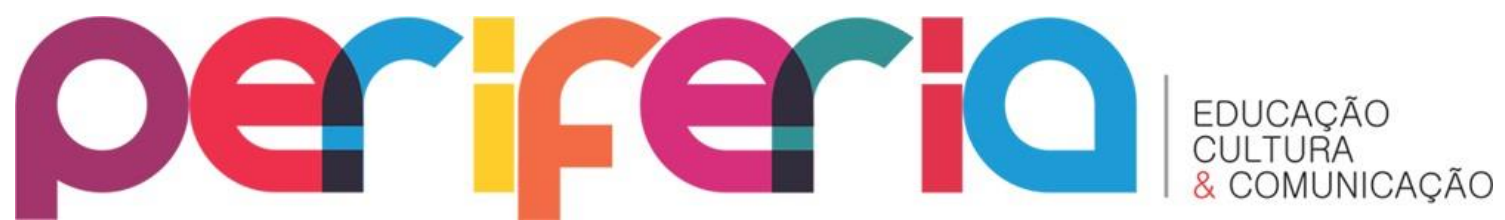

ISSN:1984-9540

DOI: $10.12957 /$ periferia.2019.36362

$\mathrm{Na}$ "interlocução", na prática discursiva, quando as palavras constituem um determinado universo do dizer, há ironia. Ela não está no locutor, não está no ouvinte, não está no texto: está na relação que se estabelece entre os três. Mesmo o que não parece irônico, pode sê-lo; depende da relação que se estabeleça. Para sermos mais incisivos, diríamos que, na ironia, joga-se com a relação entre o estado de mundo tal como ele se apresenta já cristalizado - os discursos instituídos, o senso comum - e outros estados de mundo. Essa é uma característica básica da ironia. (ORLANDI, 2012, p. 26)

Assim utilizam-se os memes, que não são discursos prontos e produzem efeitos de sentido irônico, para se expressar de forma suavizada, um recorte que permite a textualização do discurso.

Realizando esse movimento de entender o intertexto dos memes e o sentido que se instaura com o passar dos tempos, compreendemos que é importante trazer à baila a noção de memória metálica. Para Orlandi (2006), a memória metálica é aquela produzida por um construto técnico (televisão, computador, etc.) e sua particularidade é ser horizontal, não havendo, assim, estratificação em seu processo, mas distribuição em série, na forma de adição, acúmulo: o que foi dito aqui e ali e mais além vai-se juntando como se formasse uma rede de filiação e não apenas uma soma. A memória metálica produz, pois, um efeito de filiação.

Encontra-se na materialidade metálica uma horizontalidade, que é estável, perene, e pode ser materializado na tela de um computador através de um botão de busca. Antes de ser buscada em um site, ou acessada a esmo, ela é um código armazenado em um servidor, desprovido de sentidos fora de sua existência numérica. Ao assumir a materialidade metálica, o meme abandonou seu estado abstrato, que poderia ser fadado ao esquecimento, e buscou uma forma talvez mais duradoura, mais perene. (COELHO, 2014, p. 11).

Trata-se da memória que é acumulada, que tudo cabe, numérica, e por isso não é baseada no esquecimento, e sim na soma quantitativa de seus elementos. (DIAS, 2012). Não historiciza, mas acumula. (ORLANDI, 2006). Assim, os memes do Enem, que são reformulados todos os anos na época de realização das provas, são criados, recriados e replicados no/pelo meio eletrônico e não ficam fadados ao 


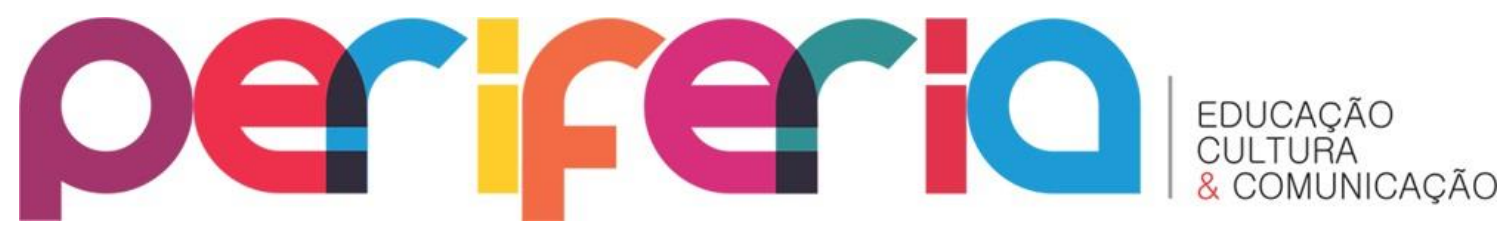

ISSN:1984-9540

DOI: $10.12957 /$ periferia.2019.36362

esquecimento em função de se configurar como uma materialidade metálica, podendo gerar outros efeitos de sentido.

Vejamos outro meme:

Imagem 3:

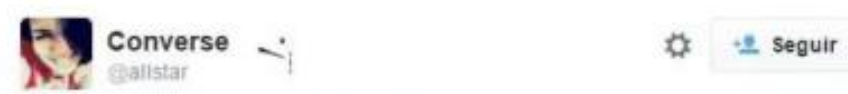

\section{Sobre o \#Enem2015}

Tema da redação vai ser o divórcio da Joelma e Chimbinha! Certezaaaa! (루유

Fonte: http://g1.globo.com/educacao/enem/2015/noticia/2015/10/memesfazem-enem-ter-mais-de-um-milhao-de-mencoes-no-twitter.html. Acesso em: 27 nov. 2015.

Mesmo após dois anos do ocorrido, ao ler o Meme 2 é possível relembrar ou buscar na memória metálica a repercussão polêmica que foi o divórcio entre os cantores Joelma e Chimbinha nas mídias e redes sociais, inúmeros foram os memes que surgiram com esse assunto. 0 Enem também não ficou fora disso.

Todos os anos, alguns meses antes da realização do exame, o assunto principal é qual será o tema da redação. Repleto de ironia, devido ao alto nível de repercussão que o fato causou, temos o Meme 2 afirmando que seria esse o tema da redação fazendo com que os sujeitos, no momento que realizam a leitura, coloquem em funcionamento o já-lá.

O interdiscurso é algo que fala antes, que surge de um lugar independente, é o que Orlandi chama de memória discursiva, é algo que já foi dito e que causa efeito no que está sendo dito. $O$ fato é que há um já dito que sustenta a possibilidade mesma de todo dizer, é fundamental para se compreender o funcionamento do discurso, a sua reação com os sujeitos e com a ideologia. A observação do interdiscurso nos permite remeter o dizer do meme "[...] a toda uma filiação de 


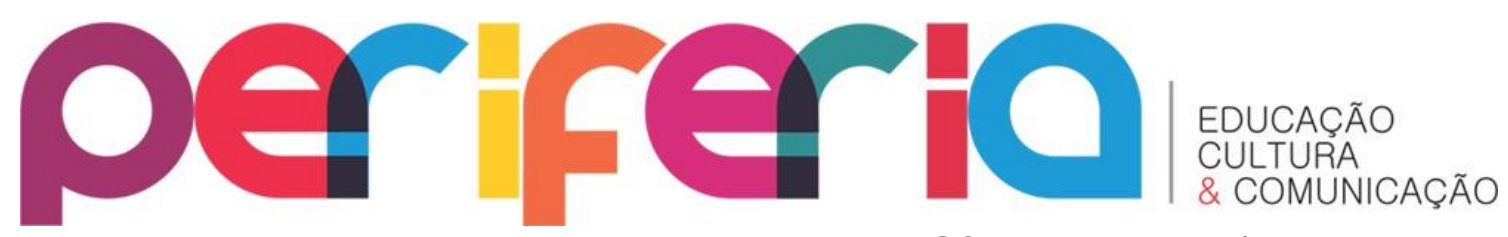

ISSN:1984-9540

DOI: $10.12957 /$ periferia.2019.36362

dizeres, a uma memória, e a identificá-lo em sua historicidade, em sua significância, mostrando seus compromissos políticos e ideológicos”. (ORLANDI, 2012b, p. 32).

No entanto, compreendemos que os compromissos políticos e ideológicos funcionam discursivamente no Meme 2 pela negação dos mesmos, pelo fato de se produzir um efeito de sentido de banalização do possível tema de redação do Enem. Bem como constrói uma crítica ao despreparo dos estudantes que realizarão o exame, remetendo à ideia de que os estudantes sabem tudo sobre os artistas e notícias banais do dia a dia e, na maioria das vezes, não possuem conhecimentos básicos de geografia, história e cultura para dissertar na redação do Enem.

Assim, compreendemos que o que é dito pelos sujeitos está inscrito em uma formação discursiva e não em outra e é disso que o discurso se constitui em seus sentidos. Entendemos, dessa ocorrência, que as palavras derivam seus sentidos das formações discursivas nas quais se inscrevem. (ORLANDI, 2012b). Por exemplo:

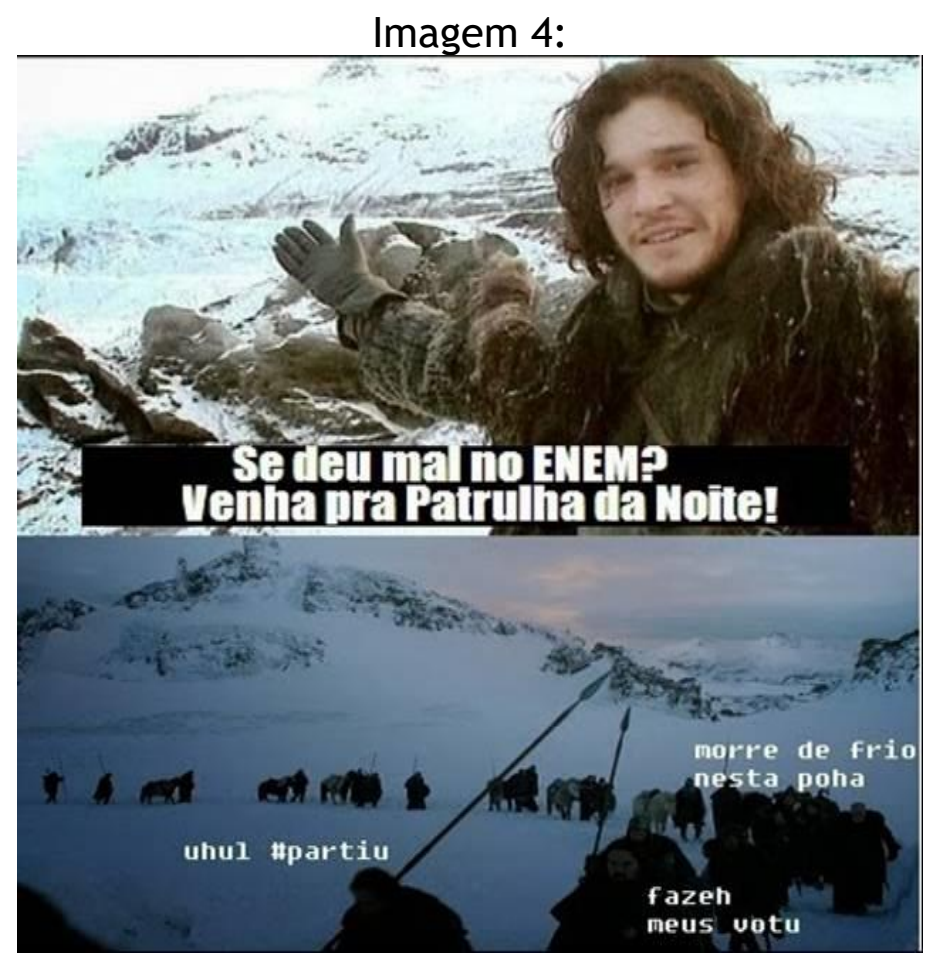

Fonte: http://g1.globo.com/educacao/enem/2015/noticia/2015/10/memes-fazem-enemter-mais-de-um-milhao-de-mencoes-no-twitter.html. Acesso em: 27 nov. 2015. 


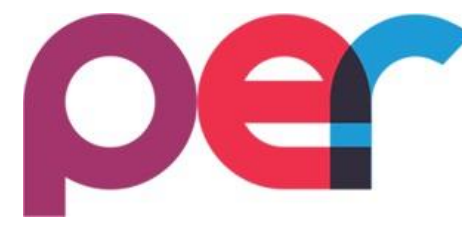

ISSN:1984-9540

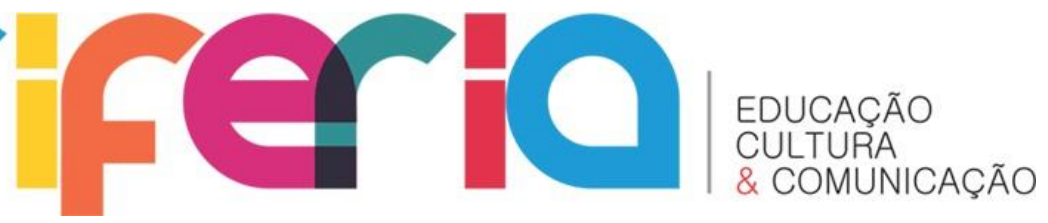

DOI: $10.12957 /$ periferia.2019.36362

O Meme 3 faz referência à série literária Game of Thrones, o primeiro livro da série de fantasia épica As Crônicas de Gelo e Fogo, do escritor George R.R Martin. 0 cenário da série é Westeros, uma terra reminiscente da Europa Medieval, na qual o inverno dura por anos ou até mesmo décadas. A história acontece em torno de uma batalha entre os Sete Reinos, desses reinos, duas famílias dominantes lutam pelo controle do Trono de Ferro, que a posse possivelmente é uma garantia de sobrevivência durante o inverno que virá. Na série, repleta de nobres, os reis possuem muitos relacionamentos fora do casamento, um deles gerou o bastardo Jhon Snow, figura central do meme em análise. Os bastardos dos reinos deveriam subir a muralha, fazer os votos de defender a corte, pois lá o frio era tão intenso que os tornaria estéreis, dessa forma, não aumentariam o número de bastardos pelo reino.

Assim, o meme, ironicamente, faz um convite, relacionando como os bastardos são tachados de fracassados e inúteis na série, aos sujeitos que não atingiram sucesso na prova do Enem e que possuem uma relação com a série, provavelmente sujeitos que a assistiram ou que leram os livros sobre as As Guerra dos Tronos. Compreendemos que é pela junção de todos os elementos mencionados que se instaura um efeito de sentido para o discurso mêmico.

Como mostra o Meme 3, essas materialidades são repletas de sentidos e foram criados em condições diferentes, pois os sentidos inscritos na materialidade discursiva possuem uma estrita relação com essa noção de condições de produção. As condições de produção remetem à exterioridade, ao contexto sócio-histórico e ideológico em que o sujeito se situa, sendo este lugar que possibilita ao sujeito uma determinada tomada de posição diante do seu discurso, produzindo determinados efeitos de sentidos. (ORLANDI, 2012a).

\section{SOBRE MEMES: THE ZOEIRA NEVER ENDS}

Como citado anteriormente, os memes são recortes que podem ser imagens, textos, vídeos ou qualquer discurso que tenha como principal objetivo comunicar de forma engraçada e divertida. 


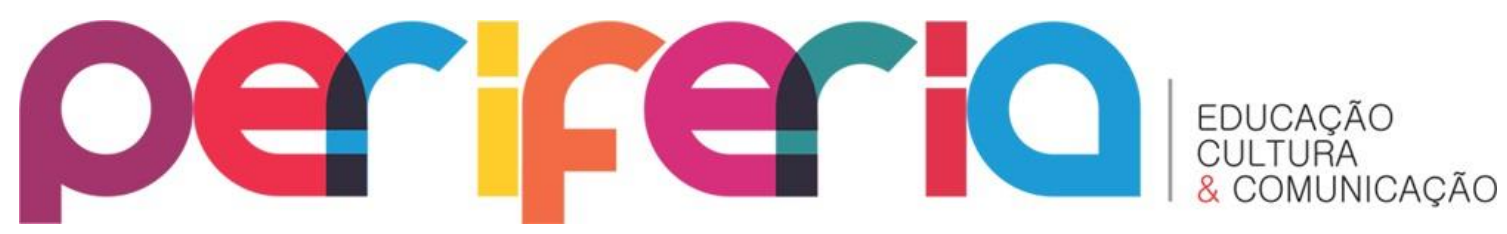

ISSN:1984-9540

DOI: $10.12957 /$ periferia.2019.36362

Os memes relacionados ao Enem buscam, de forma irônica, expor o grau de dificuldade das provas e o quão desgastante é passar por esse momento que envolve, muitas vezes, o futuro acadêmico/profissional dos alunos que apostam todas suas fichas na expectativa da aprovação, fazendo, após a prova, várias criações apresentando o que sentiram no Enem.

Zoppi Fontana (2016) explica que os memes podem ser entendidos como a união do discurso lúdico mais o discurso polêmico, sendo assim definidos a partir de Orlandi:

O discurso lúdico é aquele em que seu objeto se mantém presente enquanto tal (enquanto objeto, enquanto coisa) e os interlocutores se expõem a essa presença, resultando disso o que chamaríamos de polissemia aberta (o exagero é o non sense). 0 discurso polêmico mantém a presença do seu objeto, sendo que os participantes não se expõem, mas ao contrário procuram dominar seu referente, dando-lhe uma direção, indicando perspectivas particularizantes pelas quais se o olha e se o diz, o que resulta na polissemia controlada (o exagero é a injuria). (ORLANDI, 1996, p.15).

Os memes são compostos de textos curtos, com elementos visuais simples e repetidos em série, sendo que há sites para produção de memes, e os sentidos, por meio da replicação, espalham-se e transbordam, e é por meio desse gesto que os memes alteram-se e ressignificam-se. Zoppi Fontana (2016) também aponta que um dos objetivos primários na criação de memes é o humor, assim como o imbricamento de diferentes materialidades significantes: imagem (estática ou em movimento) escrita - som.

Considerando o funcionamento dos memes, com sua capacidade de reconfigurar-se e replicar-se na produção de sentido, empreendemos a tarefa de pesquisar, organizar e analisar as discursividades seguindo o antes, durante e após a realização do exame.

Seguindo o movimento pendular entre teoria e análise, compreendemos que os memes que são materiais digitais, compostos por imagens e textos, tendo relação com algo cotidiano, possuem em seu sentido a intertextualidade de um discurso que 


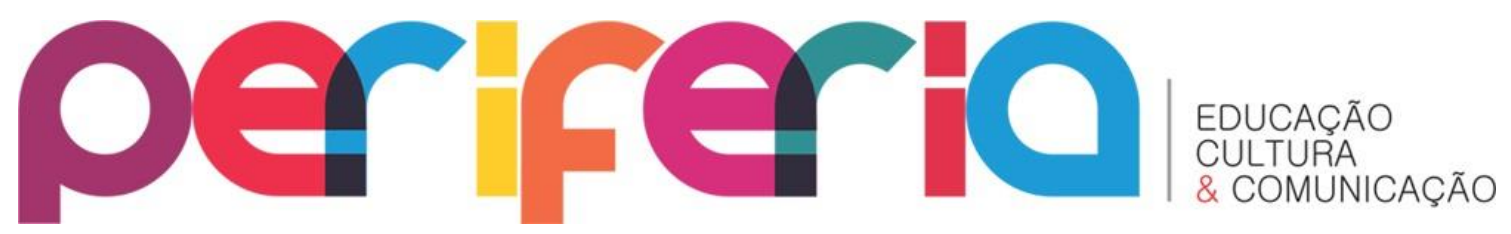

ISSN:1984-9540

DOI: $10.12957 /$ periferia.2019.36362

já foi proferido em outro momento e que está ligado ao presente. Os memes possuem a ironia como característica marcante, bem como possuem o objetivo de divertir caracterizado como discurso lúdico e o discurso polêmico que se apresenta em forma de crítica presente no intertexto do discurso que só será instaurada considerando o gesto de leitura. Também precisamos considerar:

[...] a efemeridade deste discurso, o seu modo e meio de difusão, a sua materialidade digital de caráter plástico, fluído, hipertextual, interativo e virtual (LÉVY, 1999), e a interação com o conteúdo que é mediada pelo computador.(BRASIL, 2017, p. 16).

Os memes analisados apresentam a reformulação do nome do exame, colocando em jogo a credibilidade que o exame possui, assim como apresentam certas regularidades. Devido às condições de produção em que são criados, ano após ano, os memes reconfiguram-se, mas apresentam as mesmas imagens e textos, replicam-se como algo novo, sendo que, na verdade, possuem as mesmas imagens e textos de anos anteriores, seguindo o antes durante e depois do Enem. Constatamos materialidades com as mesmas imagens nas diferentes fases do exame, afirmando a ideia de que os memes reconfiguram-se, por isso as relações interdiscursivas e intertextuais são tão importantes para a compreensão do discurso mêmico. Para tanto, consideramos que a noção de memória metálica é importante para explicar esse funcionamento:

Falar em memória metálica não quer dizer que ao enunciar o dizer não esteja determinado pela memória discursiva, quer dizer que ao circular na materialidade digital, esse dizer se filia a uma memória metálica para significar. E essa memória metálica produz uma evidência do sentido e do sujeito uma vez que não diz respeito à existência histórica do enunciado, mas à sua existência técnica, replicável. (DIAS, 2014, p. 8)

Compreendemos que os memes são discursos produzidos na e pela internet e no desenvolvimento das análises nos deparamos com um efeito de não autoria, pois os memes não têm um "nome de autor" ou autor específico. É nessa perspectiva que nos arriscamos em dizer que há, então, a tentativa de produção de um efeito de não 


\section{perferio}

ISSN:1984-9540

DOI: $10.12957 /$ periferia.2019.36362

autoria. Sobre esse funcionamento, Orlandi explica que “[...] um texto pode até não ter um autor específico, mas, pela função-autor, sempre se imputa uma autoria a ele." (2012a, p. 75).

De acordo com Orlandi (2012a), a assunção da autoria implica uma inserção do sujeito na cultura, uma posição dele no contexto histórico-social, ou seja, há determinadas condições de produção dos memes que implicam pensar o contexto/situação e os possíveis leitores. Nesse sentido, Brasil (2017, p. 98) explica que "[...] as referências ao repertório da cultura popular dizem respeito às formações discursivas compartilhadas entre os autores e determinados grupos". Assim, nos memes analisados, compreendemos que as referências fazem menção a produtos culturais, principalmente, literatura e séries que têm como público alvo, possivelmente, os mesmos sujeitos que realizam a prova do Enem. Isso também pode nos indicar as formações imaginárias acerca dos sujeitos que realizam a prova, ou seja, leitores e espectadores de determinados produtos culturais.

Nossa tentativa é de encerrar dizendo que "não há ritual sem falhas" (PÊCHEUX, 1988, p. 301), por isso, muitas vezes, os memes podem não ser compreendidos. Mesmo partindo da reconfiguração e replicação de memes já existentes e de serem discursos lúdicos e irônicos, há a possibilidade de que sujeitosleitores não entendam tais discursividades, em decorrência de que "Os memes são enunciados oriundos do agrupamento de outros discursos, que possuem no seu autor a origem das suas significações e a sustentação da coerência do sentido." (BRASIL, 2017, p. 106). 


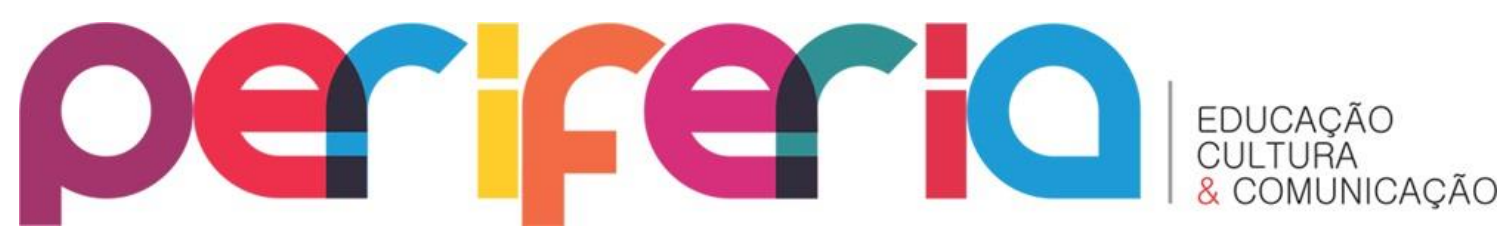

ISSN:1984-9540

DOI: $10.12957 /$ periferia.2019.36362

\section{REFERÊNCIAS}

BRASIL, Livia Maia. Memes imagéticos sobre as eleições de 2014: uma análise de discursos e representação política no Facebook / Livia Maia Brasil. - 2017. Dissertação (mestrado) - Universidade Federal do Rio Grande do Norte. Centro de Ciências Humanas, Letras e Artes.

CANDIDO, Evelyn Coutinho Rother; GOMES, Nataniel dos Santos. Memes - uma linguagem lúdica. Revista Philologus, Rio de Janeiro, ano 21, n. 63, p. 1293-1303, set./dez., 2015.

CARVALHO, Nelly; KRAMER, Rita. A linguagem no Facebook. In: Linguística da Internet. Tania G. Shepherd e Tânia G Salés. (Organizadoras). - São Paulo: Contexto, 2013

CASTELLANOS PFEIFFER, Claudia. Bem dizer e retórica: um lugar para o sujeito. 2000, $174 \mathrm{f}$. Tese (Doutorado em Linguística) - Instituto dos Estudos da Linguagem, Universidade Estadual de Campinas, Campinas.

COELHO, André Luis Portes Ferreira. Brace yourselves, memes are coming: formação e divulgação de uma cultura de resistência através de imagens da internet. Campinas, SP : [s.n.], 2014. Dissertação (mestrado). Disponível em: http://www.bibliotecadigital.unicamp.br/document/?code=000938032

DIAS, Cristiane. A língua em sua materialidade digital. Seminário de Estudos em Análise do Discurso (3. : 2007 : Porto Alegre, RS) Anais do III SEAD - Seminário de Estudos em Análise do Discurso [recurso eletrônico] - Porto Alegre : UFRGS , 2007. Disponível em: ISSN 2237-8146

A poética do cotidiano da rede. Dossier Análisis del Discurso en Brasil: teoría y práctica. Signo y Seña 24. 2013. Disponível: http://revistas.filo.uba.ar/index.php/sys/article/viewFile/131/84.

. Linguagem e tecnologia: uma relação de sentidos. In. PETRI, Verli e DIAS, Cristiane (orgs.). Análise de discurso em perspectiva: teoria, método e análise. Santa Maria: Editora UFSM, 2013.

. 0 ensino, a leitura e a escrita: sobre conectividade e mobilidade. Entremeios: revista de estudos do discurso. v.9, jul/2014. Disponível em < http://www.entremeios.inf.br >

. Análise do discurso digital: sobre o arquivo e a constituição do corpus.

Estudos linguísticos, São Paulo, 44 (3): p. 972-980, set.-dez. 2015. 


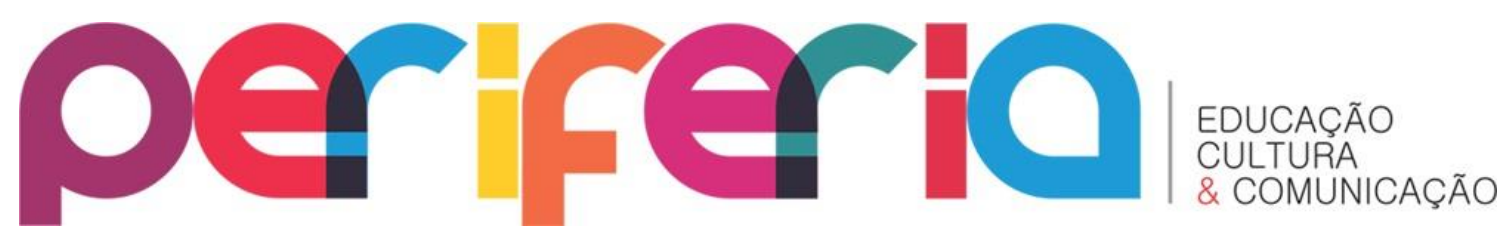

ISSN:1984-9540

DOI: $10.12957 /$ periferia.2019.36362

MARTINO, Luís Mauro Sá. Teoria das mídias digitais: linguagens, ambientes e redes. 2. ed. Petrópolis: Editora Vozes, 2015.

ORLANDI, Eni. A linguagem e seu funcionamento: as formas do discurso. Campinas: Pontes, 1996. . Interpretação: autoria, leitura e efeitos do trabalho simbólico. São Paulo, 2006.

. Análise de discurso: princípios e procedimentos. Campinas: Pontes, 2012a. . Discurso e leitura. São Paulo: Cortez, 2012b.

Discurso e texto. São Paulo: Pontes, 2012c.

PÊCHEUX, Michel. Semântica e discurso: uma crítica à afirmação do óbvio. 4. ed. Campinas: Pontes, 2009.

SCHONS, Carme Regina; FUKUE, Mário Fafael Yudi. Noções Introdutórias sobre a Função - Avatar e o Hiperdiscurso. SIGNUM: Estud. Ling., Londrina, n. 15/3 (esp), p. 343-360, dez. 2012.

SOUZA, Carlos Fabiano de. Memes: formações discursivas que ecoam no ciberespaço. VÉRTICES, Campos dos Goytacazes/ RJ, v.15, n. 1, p. 127-148, jan./abr. 2013.

ZOPPI FONTANA, Mónica G.. Argu(meme)ntando Argumentação, discurso digital e modos de dizer. [Apresentação em Power point]. In: III Seminário Internacional de Estudos sobre Discurso e Argumentação (III SEDiAr). Universidade Federal de Sergipe. São Cristóvão, 2016. Disponível em: <http://octeventos.com/site/sediar/download/argu(meme)ntando.pdf>. Acesso em: 04 nov. 2016. 